\title{
Teaching NeuroImages: Occlusion of all 4 major extracranial vessels
}

Michael T. Mullen, MD Alexander Pantelyat, MD Bryan A. Pukenas, MD Steven R. Messé, MD

Address correspondence and reprint requests to Dr. Michael T. Mullen, Department of Neurology, Hospital of the University of Pennsylvania, 3400 Spruce St., Philadelphia, PA 19104.
A 68-year-old man presented with 5 weeks of recurrent syncope and vision loss. He had orthostatic hypotension with a blood pressure drop from 145/44 $\mathrm{mm} \mathrm{Hg}$ sitting to $90 / 40 \mathrm{~mm} \mathrm{Hg}$ standing. Neurologic examination and brain MRI were normal. Angiography revealed bilateral internal carotid and vertebral artery occlusions; cerebral perfusion was provided by collateral circulation (figure). His antihypertensive medications were reduced. The orthostasis resolved, and he became asymptomatic.

Bilateral carotid and vertebral artery occlusion is extremely rare. ${ }^{1,2}$ Collateral circulation can maintain cerebral perfusion without infarction. In symptomatic patients, reducing antihypertensive drugs and/or increasing blood pressure with fludrocortisone or midodrine may be effective treatments.

\section{REFERENCES}

1. Vitek J, Halsey J, McDowell H. Occlusion of all four extracranial vessels with minimal clinical symptomatology. Stroke 1972;3:462-466.

2. Okada Y, Shima T, Nishida M, Kagawa R. Magnetic resonance angiography visualization of four vessel (bilateral carotid and vertebral artery) occlusion: two case reports. Neurol Med Chir 1998;38:28-33.
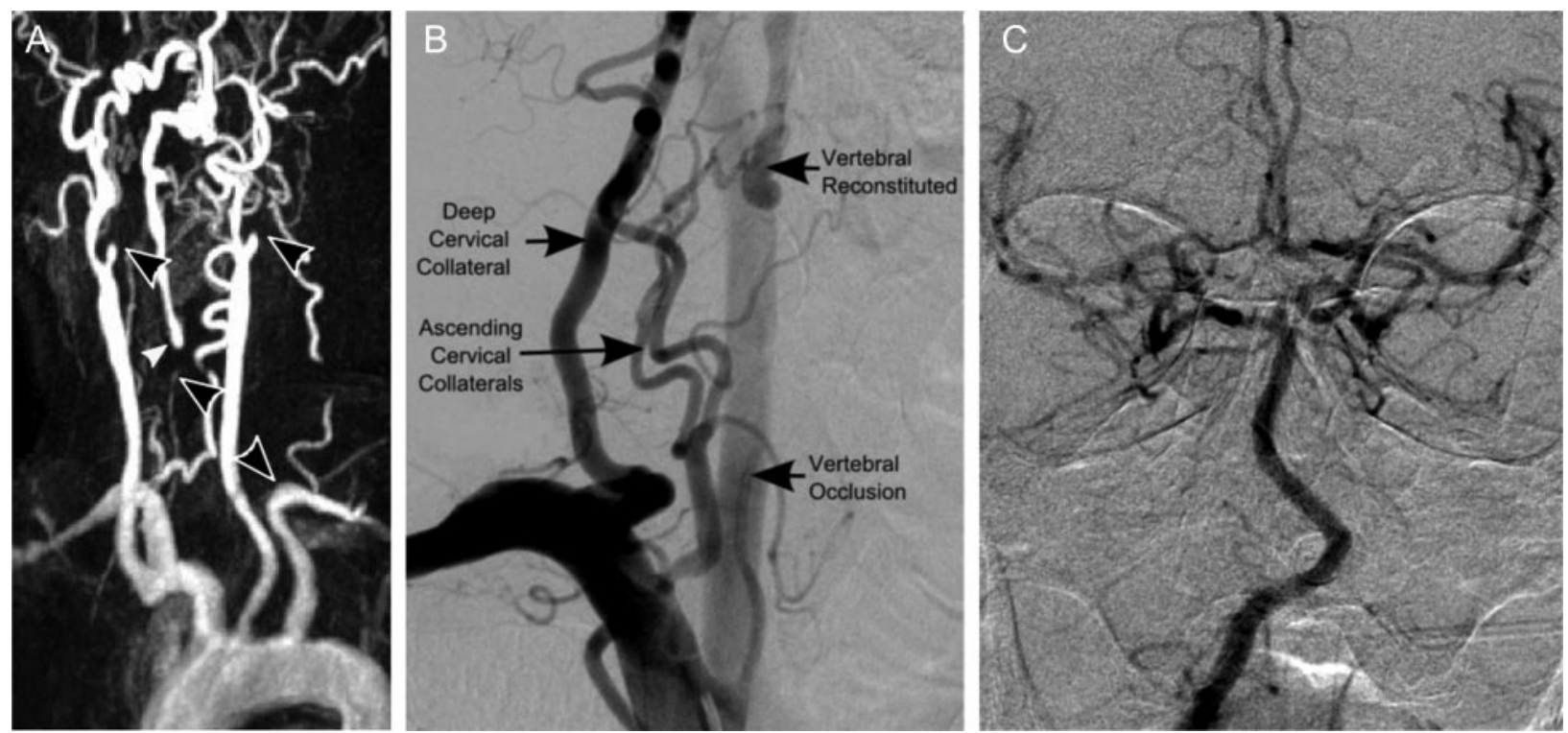

(A) Magnetic resonance angiography shows occluded internal carotid and vertebral arteries bilaterally (black arrowheads) with distal reconstitution of the right vertebral artery (white arrowhead). (B) Angiogram shows reconstitution of the distal right vertebral artery by cervical collaterals. (C) Angiogram shows right vertebral artery supplying the anterior circulation via the circle of Willis.

From the Departments of Neurology (M.T.M., A.P., S.R.M.) and Radiology (B.A.P.), Hospital of the University of Pennsylvania, Philadelphia. Disclosure: Dr. Mullen receives publishing royalties from Up-To-Date, Inc. and receives research support from the NIH (NHLBI K12-HL083772 [vascular medicine trainee]). Dr. Pantelyat and Dr. Pukenas report no disclosures. Dr. Messé receives publishing royalties from Up-To-Date, Inc.; serves on the speakers' bureau for Boehringer Ingelheim; and receives research support from Gore, the NIH (NIDDK, U01-DK060990 [endpoint adjudication committee], and NINDS U01 NS40406-04 [local PI]), and the American Heart Association. 


\section{Neurology}

\section{Teaching NeuroImages: Occlusion of all 4 major extracranial vessels \\ Michael T. Mullen, Alexander Pantelyat, Bryan A. Pukenas, et al. \\ Neurology 2010;75; 51 \\ DOI 10.1212/WNL.0b013e3181f39aca}

This information is current as of September 20, 2010

Updated Information \&

Services

References

Subspecialty Collections

Permissions \& Licensing

Reprints including high resolution figures, can be found at: http://n.neurology.org/content/75/12/e51.full

This article cites 2 articles, 1 of which you can access for free at: http://n.neurology.org/content/75/12/e51.full\#ref-list-1

This article, along with others on similar topics, appears in the following collection(s):

All Cerebrovascular disease/Stroke

http://n.neurology.org/cgi/collection/all_cerebrovascular_disease_strok

e

\section{Infarction}

http://n.neurology.org/cgi/collection/infarction

Other cerebrovascular disease/ Stroke

http://n.neurology.org/cgi/collection/other_cerebrovascular_disease_st roke

Information about reproducing this article in parts (figures,tables) or in its entirety can be found online at:

http://www.neurology.org/about/about_the_journal\#permissions

Information about ordering reprints can be found online:

http://n.neurology.org/subscribers/advertise

Neurology ${ }^{\circledR}$ is the official journal of the American Academy of Neurology. Published continuously since 1951, it is now a weekly with 48 issues per year. Copyright. All rights reserved. Print ISSN: 0028-3878. Online ISSN: 1526-632X.

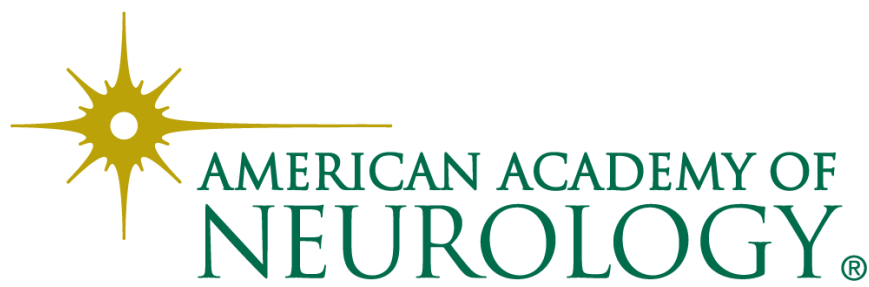

